\title{
The Application of Differentiated Instruction to a High School Student With Dyslexia in the German Language A Case Study
}

\author{
Dr. Makrina Zafiri (Corresponding author) \\ ESP/EAP Lecturer at the Center of Foreign Languages \\ Aristotle University of Thessaloniki \\ Teacher Trainer at the Greek National Training Center of ASPETE in Thessaloniki \\ Academic Associate \\ Hellenic Open University \\ Greece \\ Tel: 30-693-411-8149_E-mail: m_nzafiri@yahoo.gr \\ Vassiliki Vakalopoulou \\ Teacher of German Language, AUTh \\ MA in Special Education at the Metropolitan College of Thessaloniki \\ Greece \\ E-mail: vasilikivak@yahoo.gr
}

Dr. Vassiliki Pliogou

Academic Coordinator, School of Education, Metropolitan College of Thessaloniki in collaboration with the UEL

President of the World Organization of Early Childhood Education (OMEP) in Central Macedonia

Greece

E-mail: pliogouv@gmail.com

Received: October 3, 2019 Accepted: October 22, 2019 Published: October 29, 2019

doi:10.5296/ijld.v9i4.15724 URL: https://doi.org/10.5296/ijld.v9i4.15724 


\begin{abstract}
In recent years, dyslexia has become an important issue in the field of foreign language teaching and learning. In this research we will explore dyslexia in connection to teaching and learning a foreign language. More particularly, in this research, we will be probing into the teaching of German as a foreign language. The purpose of this research is to investigate the effectiveness of the application of Differential Instruction, the application of the Grammar -Translation Method, the Audio-Visual Method, the Communicative Approach to language teaching as well as the Multisensory Method to a Greek student with dyslexia. The girl is in the first year of junior high school and is being taught German as a foreign language at school. The research method, which was applied, focused on qualitative research through the use of semi structured interviews. This research is also a case study. Action research was conducted, for the needs of this small-scale research, through ten differentiated instruction lessons which were taught to a student with dyslexia. The student and her mother were the major sources of data collection. More particularly, the semi - structured interviews were conducted before and after the implementation of differentiated instruction with the student and her mother. We initially attempted to collect information through semi-structured interviews, on the student's family profile, and after conducting the ten lessons, we tried to verify the effectiveness of the approaches and methods which were applied. The results of this research showed that the effectiveness of differentiated instruction was immense as the student's performance improved in the foreign language.
\end{abstract}

Keywords: Differentiated instruction, case study, the German language, action research, dyslexia

\title{
1. Introduction
}

\subsection{The Common European Framework of Reference for Level A1}

The Common European Framework of Reference (CEFR) sets the foundations upon which the teaching of languages is based. It is a guideline for the preparation of relevant language curricula, examinations, school textbooks, foreign language coursebooks, etc. The Council of Europe proposes an approach based on students' communication needs and the use of teaching materials and methods, which should be in agreement with the students' needs and learning styles (Alderson, 2002). Users and learners of a language are considered to be 'social participants of a community', more particularly, as members of a society, they are called upon to complete tasks concerning a set of circumstances which exist within a particular environment (Spinthourakis, 2004).

In this study, the student is of an A1 level. For the Common European Framework of Reference, this level is the lowest identifiable 'level' of linguistic competence. The learning level aims at novice students and its main learning objectives are to enable students to use the language to purchase something, to ask and to say what day of the week it is, the date and time, to use basic greeting expressions, to enable them to use words and expressions such as 'yes', 'no', 'please', etc., to apologize and to be able to fill in simple documents with their personal information (CEFR, 2001). 


\subsection{The Curriculum}

There are open and closed/fixed/rigid types of curricula (Sawyer, 2004). The name or 'brand name' which each curriculum receives depends on the teacher's autonomy in terms of design and application (Wraga, 2017). The higher the teacher's participation in constructing a curriculum, the more open the curriculum is considered to be (Karavas \& Manolopoulou-Sergi, 2004). In this research, the curriculum is 'open' because the teachers/researchers, actively participated in the construction and 'flow' of the curriculum. The teachers plan their own activities, and students become actively involved in the educational process.

\subsection{The Syllabus}

White (1988 in Karavas \& Manolopoulou-Sergi, 2004, pp. 43-44) differentiates syllabi into Type A and B. In an A-type syllabus the teacher is responsible for setting the goals, selecting the materials through which students must be taught, what students must learn and also how students will be evaluated. In A-type syllabuses the teacher is responsible for setting the goals and selecting the materials through which students will be taught. Students are also told what they must learn as well as on how students will be evaluated (Cashi, 2016). In a Type B syllabus, the way students learn is a priority. In the present study, the Type B syllabus was applied, special emphasis was placed on the student's participation in the lesson and the ease with which she 'grasps' the new knowledge. In addition, the activities and the educational processes were structured on the basis of the student's learning profile (Richmond, 2016).

\section{Contents of the Specific Case Study}

\subsection{Teaching Method(s) and Approach(es)}

The teaching method(s) and approach(es) which were applied and the action research which was conducted were all based on the series Beste Freunde A1. Three teenagers are the main characters in all three volumes of the textbook. Their role is to portray everyday life in Germany through fun and interesting stories (Balser \& Papadopoulou, 2014).

This teaching series is specially formulated for Greek students. This is demonstrated by the use of the Greek language in the exercise book so that students can fully understand all the exercises. The teaching method(s) and approach(es) proposed by the aforementioned coursebook both provide communicative competence to the student. This is confirmed by the role of the protagonist, Anna, who comes from Greece. Anna, who is the bilingual protagonist of the series, speaks in German and tells her readers about her experiences in Greece. In this way, students learn vocabulary with which they can describe everyday situations as well as situations which take place on special occasions (e.g. in Christmas and Easter) in Greece and Germany (Balser \& Papadopoulou, 2014).

\subsection{The Teacher's Book-Description}

The teacher's book contains the teaching material as well as all the lesson plans for each teaching hour. These include games, tests, a key to all listening exercises, and all the audio transcripts (Balser \& Papadopoulou, 2014). 


\subsection{The Student's Book-Description}

The student's book consists of eighteen (18) chapters. At the beginning of each chapter, students become acquainted with one of the protagonists through a small text. Each chapter is completed after the end of three units. There are also two pages which deal with culture, mediation, and project work. The aim is to help pupils to come into contact with the German culture and compare it with the Greek culture (Balser \& Papadopoulou, 2014).

\subsection{The Exercise Book - Description}

The exercise book offers students the possibility to practice the German language through the use of additional material. In fact, there is a page with consolidation vocabulary exercises which, with the aid of accompanying images, make it easier for students to understand the new vocabulary. Additionally, there is a page with consolidation grammar exercises. Also, in the appendix section of the student's exercise book, there are specific oral exercises which aim at developing students' communicative competence (Balser \& Papadopoulou, 2014).

\subsection{The Teaching Approaches and Methods which were Applied}

The teaching methods and approaches which were applied were the Communicative Approach to language teaching, the Multi-Sensory Approach, the Audiovisual Method and the Grammar-Translation Method. The teachers/researchers took into consideration the needs of the student and based their teaching on the Communicative Approach, which in turn is based on the assumption that language teaching and learning should not be treated as individual grammatical structures but as a communication code (Bouniol \& Zouganeli, 2004). The aim of the Communicative Approach is for students to acquire language through procedures that promote the use of the language for communicative purposes (Irmawati, 2012).

The Multi-Sensory Approach, which was applied in this study, contributes significantly to the teaching of a foreign language to students with dyslexia, including the use of visual, acoustic and kinetic stimuli which, when combined, improve and enhance the memory and learning skills of students with dyslexia, especially their writing skills in the foreign language (Cimermanova, 2015). In addition to this, according to Henderson (2011), multi-sensory teaching enhances self-confidence and autonomy of students with dyslexia.

The basic principle of the Audiovisual method, in teaching a foreign language is the connection of visual materials such as images, videos, films, etc., with the oral and written part of the foreign language and this was the reason why it was applied in this study (see also Tsokoglou, 2013-2014). According to the aforementioned method of teaching spoken language is naturally acquired by students. There is no need, on the part of the foreign language teacher, to explain grammatical structures when applying the Audiovisual method (see also Balen, 2012).

The main objective of the Grammar - Translation Method is the learning of grammar rules (Bouniol \& Zouganeli, 2004). The aforementioned is based on the assumption that one 'knows' a language when he/she 'knows' the grammar rules of the language and can apply them when constructing sentences (Balen, 2012). The student's mother tongue, which is Greek, plays a key role in this method (Bouniol \& Zouganeli, 2004) as the rules are explained in the mother 
tongue, which is Greek. Grammar is transmitted in a productive manner, in the sense that these rules are explained first, then the examples are listed, and finally the rules are implemented through exercises (Balen, 2012).

\subsection{Dyslexia and the Student Under Scrutiny}

\subsubsection{Dyslexia-Definition}

Grammar is transmitted in a productive manner, in the sense that these rules are explained first then the examples are listed, and finally the rules are implemented through exercises. However, in the present study, a pedagogical definition will be used, because this research is both pedagogical and educational.

According to The Orton Dyslexia Society Research Committee, dyslexia is a prominent learning disability, of intrinsic origin. Its basic feature is the difficulty students face in decoding individual words which result, on the part of the students, in a poor phonological processing. These difficulties, in most cases, do not match the age of the child and are not the result of a genetic defect, which is also the case of the student under scrutiny. Dyslexia has degrees of difficulty in the various facets of the language with problems in reading, writing, and spelling (The Orton Dyslexia Society Research Committee, April 1994 as reported in Reid 2003, p. 4).

\subsubsection{Dyslexia and the German Language}

The German language has been described as a phonologically translucent language (Bond, 2013). This means that there is a correlation in German between the phonemes in the spoken language and the graphemes in the written language. The only difficulty, which may be found in the German language, lies in the prolonged pronunciation of the vowels. In German, three basic rules prevail in pronunciation. More specifically, the replication of vowels (e.g. Meer = Lake), the soundless ' $h$ ' before a vowel (e.g. sehen = I see) and the long 'I', (e.g. Sieg= victory) (Wolf et al., 1994).

Current German literature shows that students with problems in learning the sounds and matching the sounds to the letters tend to misspell words (Malzon \& Czycholl, 2011). This shows a lack of phonological awareness (e.g. ferstet rather than versteht), on behalf of the students. Additionally, students with dyslexia have problems in spelling. Errors in spelling produced by students with dyslexia do not differ from those errors produced by other students, but they are more frequent. Students with dyslexia seem to have difficulty in reading and spelling the following letters: / b /, / d /, / ei /, / ie /, / eu /, / v /, / f/, / / w /, / sch / (Schulte, 2008), which is also the case of the student under scrutiny. Students with dyslexia seem to have problems with written expressions too and the same goes for their reading, the aforementioned also applies to the student under scrutiny. Their reading is usually characterized as slow and toneless as a result they often don't understand the meaning of the texts which they read (Malzon \& Czycholl, 2011), as is the case of the student in this research too.

\subsubsection{Differentiated Instruction}

Differentiated instruction is based on the concept that learning is organized around a variety of 


\section{Macrothink

means and processes that are adapted to the needs, interests, and inclinations of students so as to support their personal development and their acquisition of knowledge and skills. (Bajrami, 2013). This is the reason why differentiated instruction was applied in the case of the student under scrutiny.

\section{Study Contents}

\subsection{Demographics}

The student who participated in this research is a thirteen-year-old female who is in the first class of junior high school and who has three more brothers and sisters. She was diagnosed with dyslexia when she was is the third grade of primary school and since then she has been receiving extra tuition by a special education teacher. Her parents have been very supportive with her from the first day that she was diagnosed with dyslexia. Her father is a doctor and her mother is a nurse. Both parents participate actively in the upbringing of their four children and that includes their daughter who has dyslexia. Both parents gave their permission for this research.

\subsection{The Purpose of This Research}

The purpose of this research is to investigate the effectiveness of Differentiated Instruction through the application of the Grammar -Translation Method, the Audio-Visual Method, the Communicative Approach and the Multisensory Approach to a first-year junior high school student with dyslexia in the German language. The research study was approved by both parents of the student who signed an ethics form which was given to them by the researchers. The mother of the student also participated in the semi-structured interview which was conducted by the researchers.

Based on the purpose of this research, the following research questions have been set:

- Is differentiated instruction effective in the case of this particular student?

- Does the use of the Grammar - Translation method bring about positive learning results?

- Is it useful to apply the Audio-Visual Method to teach dyslexic students?

- Is the Communicative Approach appropriate for teaching German to this particular student with dyslexia?

- Is the application of the Multi-Sensory Approach effective in teaching the German language to this particular student with dyslexia?

\subsection{The Research Method}

In the present study, the subjects under scrutiny are a dyslexic school girl and her mother. The ten differentiated lessons and interviews took place at the student's home in the wider area of the Prefecture of Pieria, Greece.

\subsubsection{The Method}

The research method is qualitative. Qualitative research aims to investigate phenomena 
through real life situations and through the participants' experiences so as to give a new dimension to the subject under consideration (Creswell, 2012; Mohajan, 2018).

\subsubsection{The Tools Which Were Used}

Based on the needs of this research, a case study research was conducted followed by action research and a semi-structured interview so as to collect data in support of our research questions. Case studies reflect real life situations and motivate teachers to combine theory and practice so as to cope with difficult situations (Zuber-Skeritt, 2001; Yin, 2014).

In the present study, the semi - structured interview was applied, the researchers asked specific questions, but were free to choose the order in which they would ask them (Stuckey, 2013). An advantage of the semi-structured interview is that it offers intimacy between the interviewer and the interviewee (Keller \& Conradin, 2018), which in combination with the facial expressions, gestures, and reactions of the person who is being interviewed, can lead to safe conclusions as concerning the truthfulness and accuracy of the interviewee's answers (Balushi, 2016). The mother's two interviews lasted for about thirty minutes (about fifteen minutes for each interview), whereas the student's interview lasted for about a quarter of an hour. The interview room was the home of the family.

The third type of research on which this study was based was action research. Action research is an alternative means of conducting research in education, in which the teachers/researchers take part in all the phases of the research, from the initial planning phase to the assessment phase and redesign (Hine, 2013). In the present study, ten lesson plans were constructed, based on the coursebook Beste Freunde A1 (Georgiakaki et al., 2014) and on the basic principles of differentiated instruction. The lessons took place in the student's home and lasted for ninety minutes each.

\subsubsection{The Structure of the Action Research}

Before the action research commenced, a pre-test was given to the student to check her knowledge, language level, and readiness. The test consisted of simple vocabulary words, grammar and A1 level writing. The teachers/researchers created ten lessons, with the aid of the coursebook Beste Freunde A1 (Georgiakaki et al., 2014) which were based on the basic principles of differentiated instruction.

\subsubsection{First Lesson}

The aim of the teachers/researchers was to encourage the student to use the vocabulary, she had learned, at the end of the lesson, to construct appropriate sentences and to make proposals, to learn about the cultural life and the geography and history of Germany and to be able to describe herself and also to introduce herself formally.

\subsubsection{Second Lesson}

The aim of the second lesson was that, by the end of the teaching hour, the student would be able to describe the materials and tools which she uses at school, such as for example her note pads, writing books, pencils, pens, rubber-erasers, etc., she would also be able to describe her 


\section{Macrothink}

International Journal of Learning and Development

ISSN 2164-4063

2019, Vol. 9, No. 4

school, her timetable and to express her opinion on the quality and contents of her school lessons.

\subsubsection{Third Lesson}

The aim here was that, at the end of the third lesson, the student would have learnt all the verbs whose subject ends in ' $d$ ' or ' $t$ ' and would also be able to use the verb sprechen (I speak), appropriately, in all its tense forms.

\subsubsection{Fourth Lesson}

The teachers/researchers based the lesson on the principles of differentiated instruction and presented the theme of 'Christmas'. The aim of this lesson was to familiarize the student with Christmas customs and to help her learn vocabulary connected to Christmas wishes.

\subsubsection{Fifth Lesson}

The purpose of this lesson was to revise what the student had been taught in previous lessons. She was also expected to be able to say how well she knows and can speak German as a foreign language.

\subsubsection{Sixth Lesson}

The aim of this lesson was to teach the student new vocabulary and to enable her to use the indefinite article by the end of the teaching lesson.

\section{3.3.7 Seventh Lesson}

The aim of this lesson was to revise and apply what was taught in the previous lesson as well as to teach the student the objects which she uses at school, such as pens, pencils, rulers, etc.

\section{3.3.8 Eighth Lesson}

The main aim of this teaching hour was to revise what the student had been taught in the last three lessons and to help practice her oral speech.

\subsubsection{Ninth Lesson}

The purpose of this lesson was to teach the student the causative form and to help her learn new vocabulary.

\subsubsection{Tenth Lesson}

The main objective of this lesson was to revise what the student was taught in the previous lesson and to teach her the verb möchten (I would).

\section{The Analysis of the Results of the Action Research}

\subsection{The Results of the "Pre-Test"}

The pupil's performance was very good. The only errors found were grammatical and of an editing nature. More particularly, errors were found in the position in which the verbs were placed within the sentence and in the endings of some verbs. 


\subsection{The Grammar - Translation Method}

For the grammar activities, the student needed more time to interpret and understand the grammar rules. It is worth noting that in trying to understand the grammar and syntax rules she was quite hesitant and made quite a few verbal mistakes. This was as expected, as this method of teaching does not teach students how to use language but limits itself to teaching grammar rules to students (Bouniol \& Zouganeli, 2004). In particular, the endings of the verbs which the student used were not correct, and her work also presented syntax errors (e.g. verb and subject inversion and vice versa). There were also weaknesses found in the oral production of the student as this method places more emphasis on writing (Tsokoglou, 2013-2014). Additionally, she encountered several difficulties when it was necessary for her to combine the knowledge which she already had to produce something new. This method posits that, a foreign language is made up of individual chunks of language which a student learning the specific foreign language should acquire, and that learning a foreign language is restricted to learning the specific rules of the language (Neuner \& Hunfeld, 1993). Given the aforementioned, it comes as no surprise that the student was unable to connect her knowledge into a coherent whole, thus producing new knowledge.

\subsection{The Audio-Visual Method}

The Audio-Visual method was used, mainly, to introduce the student to the subject of the new lesson in order to help her combine visual and audio information (Balen, 2012). In this kind of activity, the student's reactions were very positive because, in all cases, she showed a willingness to describe the pictures she saw or videos she watched. This method has been extensively used to interpret vocabulary through images. In the case of this research, and for the learning needs of the specific student, this method was applied, quite regularly, in web-based exercises. One of the techniques, which was applied in the case of this student, was games with word cards. These visual stimuli functioned effectively in introducing novel vocabulary words to the student and they also helped the student to memorize the new vocabulary (Balen, 2012). At this point it is worth noting that during the lesson there was regular collaboration between the teachers/researchers and the student. Through the elicitation of information, from pictures and examples of dialogues, the student managed to construct her own dialogues (aided by the teachers/researchers). In most of these activities, the student needed more time than was allotted, her speech was slow, toneless, with several mistakes in the pronunciation of the words.

\subsection{The Communicative Approach}

As concerning the activities which the student was expected to finish it was once again clear that the student needed more time than the time which was allotted to her. The teaching of grammar seemed to be more enjoyable for the student, because she was encouraged to 'discover' the grammar rules on her own, through the use of visual stimuli (Tsokoglou, 2013-2014), coupled with the use of specific questions which the teachers/researchers asked the student. Through the use of comics, the student was called upon to construct similar dialogues with the teachers'/researchers' aid, but without following the initial pattern suggested by the comics. Once again, the student seemed to face the same difficulties, as 
aforementioned. However, this was something which was expected in the context of this approach, because grammar is not emphasized upon and is also not considered particularly important (Bouniol \& Zouganeli, 2004). However, over time, the student's oral speech improved significantly.

\subsection{The Multi-Sensory Approach}

The present study focused on the use of the multi-sensory approach, which enabled the student to perceive the contents of the material, the syllabus and the curriculum (Gerold \& Norbert, 2007). More particularly, the following computer and online platforms were applied: www.learningsapps.org and www.pixtom.com, which the student used so as to complete her activities and to use her sense of hearing and vision. This approach worked well with the student, whereas the other methods and approaches did not (Sharan, 2014). The difficulties which the student faced were quite a few namely the writing of consecutive strings of words or sentences (e.g. Geschichte = history), as well as with words which consisted of the 'voiceless' ' $h$ ' (e.g. Schere $=$ scissors) and the replacement of the letter ' $v$ ' with the letter ' $f$ ' (e.g. ferstet instead of versteht $=$ understands). Letter reversal was also intense (e.g. Bliestift instead of Bleistift $=$ pencil).

\subsection{The Results of the "Post Test"}

The Post - Test results demonstrated the effectiveness of differentiated instruction throughout the lessons which were conducted. In her vocabulary exercises, the student wrote some words in English because, as she said, she could not remember them in German, and the grammar exercises showed that she had not fully understood the use of the causative form and the nominative form. On the other hand, in the exercises which dealt with making sense of what was presented to her in the form of written language, no mistakes were found because oral conversations were conducted earlier during the lesson, in which she used the same language and vocabulary.

\subsection{The Interview Results}

What follow are the results of the semi -structured interview which was conducted.

\subsubsection{The First Axis}

As concerning the axis of the first the group of questions, which the researchers received from each subject, the mother replied that she had studied nursing and that she had graduated from the Technical Institute. The student attended the first class of Junior High School. The student also responded on how she felt about her school and her preference in specific school subjects. The researchers also asked the mother questions about the educational background of the girl's father, his profession, as well as her own profession.

\subsubsection{The Second Axis}

In the second axis the subjects were questioned about the emotions caused by the syndrome of dyslexia. The mother seemed to have fully accepted her child's situation and her aim was now to encourage and support her child (Alias \& Dahlan, 2015). Dyslexia, according to the student 
herself, has played a significant role in her psychological and emotional balance, because she realized - with the help she received from a psychologist - that dyslexia should not be a barrier in her emotional and educational development.

\subsubsection{The Third Axis}

The third thematic axis includes questions about the student's treatment within the school environment. The mother was asked how the school treated her and her child. She replied that when her child attended elementary school, she was very satisfied with the aid and support her child received at school from the special education teacher. At this point, it appears that the views of the mother and the student differ as the student did not refer to the help, she received from her special education teacher in her school's parallel support. As far as her class teachers in primary school were concerned, the mother mentioned that they were indifferent to her daughter. Sometimes their behavior could even be characterized as detrimental to her child's psychology (Rontou, 2010).

\subsubsection{The Fourth Axis}

The fourth axis explores the cognitive strategies which the student applied so as to understand the course material. According to her mother, she (her daughter ' $M$ ') showed a great improvement in the fifth and sixth classes of Primary School because of the help she received from her special education teacher in her school's parallel support. She also reported that since dyslexia was diagnosed, M. was supported by a special education teacher at home.

\subsubsection{The Fifth Axis}

The fifth axis includes the techniques, approaches, and methods used to help the dyslexic student in the foreign language lesson. According to the student, the effectiveness of differentiated instruction was enormous, and so were the multisensory and the audio-visual methods which were provided to her by her teachers/researchers at home. The long-term effects of the aforementioned methods and approaches were very vivid, and this was noticeable in the student's performance during the lesson and in the results of her post-test. The student expressed her preference for the activities in which carton paper was used, as well as other objects such as toys and tools. She mentioned that, though the illustrations in her book caused positive emotions, the computer exercises she was asked to complete had an even greater impact on her learning because they had an innovative design and very bright colors and drawings (Balen, 2012).

\subsubsection{The Sixth Axis}

The sixth axis focused on the student's performance and her stance concerning the lesson that took place in the classroom. According to her mother, the teacher at school did not realize that M. had dyslexia. This may, perhaps, have been due to her (meaning the teacher's) lack of knowledge on dyslexia (Chourmouziadou, 2016) or the fact that German is a translucent language (Bond, 2013). Regarding the student's opinion on the lessons she attended at school, the student expressed her distaste. 


\subsubsection{The Seventh Axis}

This axis refers to the need to diversify the educational process. The mother mentioned that there is a need, on the part of the teachers, to attend training seminars. At this point, the views of the mother and the student converge as both said that no other extra material is used at school other than the school's textbook.

\section{Discussion}

The results of this research showed that the methods, approaches, and techniques which were used for this specific teaching process answered the initial research questions which were set by the researchers.

As concerning the first research question, which regards the effectiveness of differentiated instruction, it seems that differentiated instruction contributed significantly to the teaching and learning of German by the student with dyslexia. The student had a positive stance towards the use of her computer through which she completed her exercises, commented on the pictures she saw and the videos she watched, as the aforementioned activated her interest and attracted her attention (Sharan, 2014).

As far as the second research question was concerned, the activities which dealt with the Grammar Translation Method caused some difficulties to the student mainly because she had a problem with the management of her time. She focused on learning the grammar rules of the foreign language rather than on producing verbal language which requires a combination of knowledge and skills (Bouniol \& Zouganeli, 2004). Unfortunately, this often led to the disinterest of the student towards the foreign language. Thus, it is understood that, despite the efforts made by the student, this method of teaching was inappropriate for this particular student, and did not meet the requirements of the textbook which was used (Georgiakaki et al., 2014) while at the same time it clashes with the proposals made by the Common European Framework of Reference (CEFR, 2001).

As concerning the third research question, according to the findings of the present research, the Audio-Visual Method of teaching seemed to have positive results on the student's learning. It turned out that the colorful pictures which were used during the lesson and the videos which the student watched were very effective, as the she showed great interest in them and at the same time, she was able to remember the vocabulary which she had learned (Balen, 2012). However, she still had a problem with the management of her time, especially the time slots which were allotted to each activity. She simply couldn't finish her activities within the given time limit. She also had difficulties in pronouncing words which had more than three syllables and was also unable to memorize dialogues (Adina, 2014). As concerning the findings presented above it is very clear that the student shows a preference in the use of images, colors and sounds. (see also Nikolaou et. al., 2017).

In all the activities in which the Communicative Approach was applied, the student seemed to have the same time management problem and sometimes made errors in syntax. At this point it is worth mentioning that as time went by and because the activities, tasks, and exercises which the student completed met her interests and were of her age group and language level, she made 
progress in her oral discourse and her communication skills improved too as she was expected to change roles frequently when role-playing (Costenaro et al., 2014). The Communicative Approach was considered suitable for the particular student because, through its use, the student was able to respond exceptionally well to all the exercises, tasks, and activities which she was asked to complete.

The Multi-Sensory Method played a crucial role in answering the fifth research question. The use of new technologies, especially the use of the computer in teaching students with dyslexia is a novelty in recent years (Drigas \& Dourou, 2013). The use of the computer for the needs of this research helped the student with dyslexia and worked as an aid in promoting the learning needs of the particular student. For all of the activities, which the student was asked to complete, she not only showed great enthusiasm, but she also showed a deep understanding of the contents of the material which she was taught. This fact makes it quite clear that the application of differentiated instruction, aided by the use of technology, plays an important role in the teaching of German, as a foreign language, to this specific student but also to students with dyslexia in general, as research shows (Sharan, 2014).

\section{Conclusion}

This research focused on one student with dyslexia and her mother who participated in the semi-structured interview. For the needs of this research, and to achieve the purposes and aims set by the researchers, a combination of research methods were applied, thus triangulating this research (i.e. case study, semi-structured interviews, etc.). Ten different, in content, lessons were produced with the aim to enhance the student's reading, writing, speaking, and listening skills. Differentiated instruction was applied, with the aid of technology, and four different Teaching Methods and Approaches were used by the teachers/researchers. The results of the present research proved that differentiated instruction was successful in teaching a foreign language, but the teaching methods which were applied also played a very important part in the teaching and learning process. The Grammar Translation Method proved ineffective for the student, whereas the Audio-Visual Method and the Communicative Approach were both more student friendly. It seems that the most appropriate method for teaching the foreign language was the Multi-Sensory Method, as it encouraged and motivated the student to learn and promoted her learning skills. This research showed that differentiated instruction in connection with the application of the Multi-Sensory Method and the use of technology effectively aided the student in her learning process.

There are three important limitations to this research firstly, we only had one subject (the girl), and her mother from which we drew our conclusions. Secondly, the limited time available to conduct the research. Thirdly, the environment in which the research took place, i.e., the student's home, which does not meet the needs of teaching a foreign language such as German, due to the fact that there is lack of equipment. However, the successful completion of the ten lessons and the positive response of the student to all the activities which took place during the lesson allow for safe conclusions to be drawn on the effectiveness of differentiated instruction.

Over the years foreign language learning is becoming more and more important in Greece and is considered to be one of the most important cultural creations of human civilization 
(Robinson, 2016). For more in-depth research into the effectiveness of differentiated instruction and the methods which should be employed, it is suggested that research be conducted on larger groups of students, given the fact that dyslexia is of a special nature and its symptoms vary (Nebraska Department of Education, 2016). The ultimate aim of this research paper was to promote and protect people's fundamental right to education.

\section{Acknowledgements}

The authors would like to thank the student and the mother for participating in this research.

\section{References}

Adina, S. O. (2014). Methoden des Fremdsprachenunterrichts. Annals of Faculty of Economics, 1(2), 131-134.

Alderson, J. C. (2002). Case studies in the use of Common European Framework of Reference. Strasburg: Council of Europe. Advanced online publication. Retrieved from https://www.coe.int/t/dg4/linguistic/Source/case_studies_CEF.doc

Alias, N. A., \& Dahlan, A. (2015). Enduring difficulties: The challenges of mothers in raising children with dyslexia. Procedia - Social and Behavior Sciences, 202, 107-114. https://doi.org/10.1016/j.sbspro.2015.08.213

Ayakli, C., Karavas, E., Manolopoulou - Sergi, E., \& Spinthourakis, J. A. (2004). Course Design and Evaluation, Vol. I, Patras: Hellenic Open University. [in Greek]

Balen, A. (2012). Methoden des Fremdsprachenunterricht (Master's thesis). Retrieved from http://darhiv.ffzg.unizg.hr/id/eprint/2172/1/Ana\%20Balen.pdf.

Bajrami, I. (2013). The importance of differentiation in supporting diverse learners. Journal of Education and Practice, 4(22), 149-154. Retrieved from https://www.iiste.org/Journals/index.php/JEP/article/viewFile/8339/8675

Balser, A., \& Papadopoulou, M. (2014). Beste Freunde 1. Deutsch für Jugendliche Lehrerhandbuch. Athens: Hueber Hellas.

Balusi, K. A. (2018). The use of online semi-structured interviews in interpretive research. International Journal of Science and Research, 7 (10), 727-732. https://doi.org/10.21275/ART20181393

Bouniol, P., \& Zouganeli, K. (2006) (eds.). Teaching English to young learners. Introduction and Theories of Child Language Acquisition. Patras: Hellenic Open University. [in Greek]

Cashi, A. (2016). The English Language Syllabus in Sweden and Japan. A Comparative Study. Kalmar Växjö: Linnen Universitetet. Retrieved from http://www.diva-portal.org/smash/get/diva2:941743/FULLTEXT01.pdf

Chourmouziadou, C. M. (2016). Primary School Teachers' Knowledge about Dyslexia: The Greek Case. Retrieved from https://www.researchgate.net/publication/327656064_Primary_school_teachers'_knowledge_ 
about_dyslexia_the_Greek_case

Cimermanova, I. (2015). Teaching English as a Foreign Language to Dyslexic Learners. In Pokrivčáková, S. et al. (eds.), Teaching Foreign Languages to Learners with Special Education Needs: e-textbook for foreign language teachers. Nitra: Constantine the Philosopher University. https://doi.org/10.17846/SEN.2015.39-62

CEFR. (2001). Common European Framework of References for Languages: Learning, Teaching, Assessment. Strasburg: Council of Europe-Language Policy Unit. Retrieved from https://rm.coe.int/16802fc1bf

Costenaro, V., Daloiso, M., \& Favaro, L. (2014). Teaching English to Young Learners with Dyslexia. Developing Phonemic Awareness through the Sound Pathways. EL.LE, 3(2), 209-230. Retrieved from http://edizionicafoscari.unive.it/media/pdf/article/elle/2014/2/art10.14277-2280-6792-324.pdf

Creswell, J. W. (2012). Educational Research. Planning, Conducting, and Evaluating Quantitative and Qualitative Research (4th ed.). Boston: Pearson. Retrieved from http://basu.nahad.ir/uploads/creswell.pdf

Drigas, A., \& Dourou, A. (2013). A Review on ICTs, E-Learning and Artificial Intelligence for Dyslexic's Assistance. IJET, 8(4), 63-67. https://doi.org/10.3991/ijet.v8i4.2980

Georgiakaki, M., Bovermann, M., Graf-Riemann, E., Seuthe, C., \& Mavroudi, A. (2014). Beste Freunde A1. Athen: Hueber Hellas.

Gerold, B., \& Norbert, P. (2007). Lernen mit allen Sinnen - Qualitätsvolle und positive Lernerfahrung. Retrieved

from https://www.iqesonline.net/assets/FCKeditor/file/3-3_Lernen $\% 20$ mit $\% 20$ allen $\% 20$ Sinnen $\% 2$ 0-\%20Qualit\%C3\%A4tsvolle\%20und\%20positive\%20Lernerfahrung.pdf

Hine, G. S. C. (2013). The importance of action research in teacher education programs. Issues in Educational Research: Special Issue, 23(2), 151-163. Retrieved from http://www.iier.org.au/iier23/hine.html

Irmawati, N. D. (2012). Communicative Approach: An Alternative Method Used in Improving Students' Academic Reading Achievement. Canadian Center of Science and Education, 5(7), 90-101. https://doi.org/10.5539/elt.v5n7p90

Karavas, E., \& Manolopoulou-Sergi, E. (2004). Course Design and Evaluation: Evaluation, Innovation and Implementation (Vol. III). Patras: Hellenic Open University. [in Greek]

Keller, S., \& Conradin, K. (2018). Semi-Structured Interviews. SSWM. Retrieved from https://sswm.info/planning-and-programming/decision-making/gathering-ideas/semi-structur ed-interviews.

Malzon, E. M., \& Czycholl, K. (2011). Schwierigkeiten im Erwerb von Lesen und Rechtschreiben. Stuttgart: Landesinstitut für Schulentwicklung.

Mohajan, H. K. (2018). Qualitative Research Methodology in Social Sciences and Related 
Subjects. Journal of Economic Department, Environment and People, 7(10), 23-48. https://doi.org/10.26458/jedep.v7i1.571

Nebraska Department of Education Office of Special Education (2016). Technical Assistance Document for Dyslexia. Retrieved from https://www.education.ne.gov/wp-content/uploads/2017/07/Dyslexia_1.20.16.pdf_

Neuer, G., \& Hunfeld, H. (1993). Methoden des fremdsprachlichen Deutschunterrichts. Eine Einführung. Berlin: Druckhaus Langenscheidt.

Nikolaou, X., Zafiri, M., \& Pliogou, V. (2017). The Implementation of Differentiated Instruction in English Language Learning to Students with Dyslexia in A' Senior Class (A1) in an English Language Center: An Action Research. Journal of Studies in Education, 7(3), 130-145. https://doi.org/10.5296/jse.v7i3.11495

Reid, G. (2003). Dyslexia: A Practitioner's Handbook ( $3^{\text {rd }}$ edition). Chichester: Wiley.

Robinson, L. (2016). Learning a Foreign Language provides a Lifetime of Cultural Enrichment. Advanced online publication. Retrieved from http://ocm.auburn.edu/newsroom/news_articles/2016/09/learning-a-foreign-language-provide s-a-lifetime-of-cultural-enrichment.php_

Rontou, M. (2010). Provision for Students with Dyslexia in EFL: An Ethnographic Case Study (Degree thesis). from https://etheses.bham.ac.uk/id/eprint/1237/1/Rontou10EdD.pdf

Sharan, N. (2014). Computer: A Tool for Assisting Students having Dyslexia (Master's thesis). Retrieved from http://www.diva-portal.org/smash/get/diva2:728104/FULLTEXT01_

Spinthourakis, J. A. (2004). Introduction to key curriculum development concepts. In C. Ayakli, K. Karavas, E. Manolopoulou-Sergi, \& J. A. Spinthourakis. Course Design and Evaluation: Introduction to Key Concepts (Vol. 1, 19-77). Patras: Hellenic Open University.

Tsokoglou, A. (2013-2014). Die Grammatik im Daf Unterricht. Hauptstudium: DGD 60 Grammatik im DaF- Unterricht. Retrieved from https://eclass.uoa.gr/modules/document/file.php/GS289/1.\%20Die\%20Grammatik\%20in\%20 den\%20Methoden\%20der\%20Fremdsprachendidaktik.pdf

Yin, R. K. (2014). Case Study Research. Design and Methods (2th ed.). London: Sage Publications.

Zuber-Skeritt, O. (2001). Action Learning and Action Research: Paradigm, Praxis and Programs. In J. Sankara, S. Sankara, B. Dick, R. Passfield (eds.), Effective Change Management through Action Research and Action Learning: Concepts, Perspectives, Processes and Applications (pp. 1-20). Australia: Southern Cross University Press, Lismore. 


\section{Macrothink}

International Journal of Learning and Development

ISSN 2164-4063 2019, Vol. 9, No. 4

\section{Copyright Disclaimer}

Copyright for this article is retained by the author(s), with first publication rights granted to the journal.

This is an open-access article distributed under the terms and conditions of the Creative Commons Attribution license (http://creativecommons.org/licenses/by/4.0/). 